\author{
Hres Yu. O., \\ PhD. in Law, \\ Associate Professor of the Department of Criminalistics \\ National University "Odesa Law Academy"
}

\author{
Dyntu V.A., \\ PhD. in Law, \\ Associate Professor of the Department of Criminalistics \\ National University "Odesa Law Academy"
}

\title{
FEATURES OF USE OF SPECIAL KNOWLEDGE WITH THE PURPOSE OF INTRODUCING PERSONALITY OF CRIME
}

\begin{abstract}
Summary. During the investigation the investigator faces an important and quite sophisticated task of the establishment of the guilty person, its detection and detention in order to prosecute. The success and effectiveness of such an activity depends on the investigator's ability to work with the information and take advantage of the variety of tools available to him, among which important place belongs to a special knowledge.

During the investigation investigator can use his special knowledge, as well as he can utilize the aid of specialists and experts. Such special knowledge can be used to search and preliminary evaluation of certain information by investigators and specialists, for the purpose of advising before and during the investigation, in the form of expert research.

Special knowledge of the investigator, specialist and expert allow to reveal various information that can indicate the characteristic features of appearance, character, behavior of the person of an unknown criminal. Assessing the situation from the point of view of the use of specialized knowledge allows us to model the identity of an unknown offender, which is extremely important especially at the initial stage of the investigation.

The use of specialist knowledge allows the investigator to detect the existence of certain negative circumstances at the scene. Timely identification of circumstances that do not reflect the true picture of the criminal event avoids making wrong decisions and making mistakes. Also, the detection of negative circumstances can lead the investigator to choose the right direction for the investigation.

An important area of use of specialized knowledge in the search and identification of the offender is the application of knowledge in the field of information technology. Today, the investigation of many crimes requires the investigation of crimes that remain in cyberspace.
\end{abstract}

Key words: crime, trace, material traces, perfect traces, person of the offender, special knowledge, cybercrime, cyberspace, virtual footprints.

Formulation of the problem. Crime detection and investigation is a complex process information searching. It is aimed at knowing the whole criminal event, its individual circumstances. Moreover, it is directed to determine the circumstances that preceded the commission of the crime and may have occurred after it was committed.

The process of crime investigation is related to the significant intellectual efforts of the investigator and other participants of the investigation. The ultimate purpose of the aforementioned cognition is to identify the offender, the formation a strong evidence base and transfer the materials of criminal investigation to court with the aim of bringing the perpetrator to justice.

It should be noticed, that the scientific papers of many domestic and foreign forensic scientists and criminalists are dedicated to the issue of determining the nature of the investigation process, its stages, objectives, and features of implementation.

Among them are Yu.P. Alenin, L.I. Arkusha, R.S. Belkin, A.N. Vasylyliev, V.I. Hromov, L.Ya. Drapkin, A.V. Dulov, Ye.P. Ishchenko, A.N. Kolesnichenko, V.S. Kuzmichov, I.M. Luzghin, Ye.D. Lukianchykov, V.H. Lukashevych, V.O. Obraztsov, L.D. Samyhin, V.V. Tishchenko, Yu.M. Chornous, V.M. Shevchuk, V.Yu. Shepitko, V.I. Shykanov and others. Methodological basis are at the heart of the latest scientific research of ways to optimize and refine the investigation process. They are embedded in the scientific papers of mentioned above researches.

Since the reformation of domestic criminal procedural legislation, informatization of society and improvement of forms and methods of criminal activity, demands from criminalistics constant updating of the tools for crime combating comply with the needs of the practice.

Therefore, the issue of the use of special knowledge in crime investigations deserves special attention, for solving a number of tactical and strategic tasks that underpin the organization and planning of the entire investigation. Their research determines the purpose of the article.

Outline of the main research material. Various aspects of the use of special knowledge during the investigation have been considered by many forensic scientists as: T.V. Averianova, L.Yu. Arotsker, V.P. Bakhin, R.S. Bielkin,A.I. Vinberh, V.H. Honcharenko, H.L. Hranovskyi, H.I. Hramovych, A.V. Ishchenko, P.P. Ishchenko, N.I. Klymenko, V.O. Konovalova, M.V. Kostytskyi, V.K. Lysychenko, V.H. Lukashevych, O.R. Rossynska, M.V. Saltevskyi and others. However, not all of the problematic issues regarding the nature and content of specialist knowledge, their forms and potential impact on investigation received a final and unconditional solution. In particular, solving such a strategic task as identifying the offender [13, c. 154], quite often it requires the use of specialist knowledge of the investigator, prosecutor, specialist or expert. This issue still remains relevant and requires the close attention of scientists. This is due to the constant development of technical and natural sciences, and adaptation of their achievements to the needs of investigative and expert 
practice. In addition, the informatization and technologicalization of society leads to the expansion of spheres of human activities, as well as to expand the spheres of criminal activity.

It should be emphasized that forms of usage of special knowledge to obtain information about an unknown offender and the identification of his personality can be quite diverse.

Firstly, a variety of investigative actions and unspoken investigative actions are a procedural means of gathering information about the circumstances of a criminal event. During the aforementioned investigative actions special knowledge can be applied directly by the investigator or by using the aid of a specialist. It can be done while searching, detection, fixation, removal and preliminary investigation of certain objects, documents, traces and crime scene. Model of crime can be built by comprehensive and deep understanding material reflection of the crime and criminal behavior of a person, conditions and psychological processes of the criminal event [7, c. 79]. Moreover, it allows to simulate the identity of the offender his anthropological, socio-demographic, and psychological (psychological-behavioral) portraits [6]. The success of the process of modeling the offender's personality directly depends on the investigator's personal ability or with the aid of specialist, analyze and evaluate each element of the scene of crime, and in their relationship with each other.

From our point of view, Separate study of traces, objects and documents has declarative nature, allows to evaluate the general characteristics and properties of the object which left the track, or evaluate an information, which contained on the surface of detected objects and documents, or in their contents.

However, the application of the study of traces, objects, and documents is acquired in the course of analysing the relationships that exist between them. The analysis of such relationships in aggregate allows us to build a three-dimensional picture of the criminal event, the identity of the offender and his behaviour. In most cases, the proper assessment of the traces, objects and documents directly depends on the timeliness and completeness of the application of certain special knowledge. Including in those cases, when the traces of the crime are forged by the criminal and the objects or documents were intentionally modified or tampered with to conceal the very fact of the criminal event, motives for committing a crime or personal involvement in the offense.

Initially investigating the crime identifying and searching for the personality of an unknown offender directly depends on the objectivity of the preliminary assessment by the investigator or specialist of all traces of the crime (in their broad sense [For more information, see.: 4]) and timely identification of traces of staging negative circumstances. Yu.P. Alenin and V.V. Tishchenko consider the mockery of a crime as a form of creating criminal evidence to mislead [1, c. 15], thus returning his attention from the identity of the perpetrator. Ye.M. Rozhyk proposes to consider negative circumstances as one of the consequences of a crime which is part of a double reflection of a criminal event both in the mind of the offender and the investigator [11, c. 130-131]. Thus, the detection of negative circumstances has double importance to the investigation: on the one hand, the timeliness of certain changes made by the offender in the crime scene allows the investigator to avoid choosing the wrong direction of investigation, on the other - it allows you to make assumptions about certain special skills of the offender (especially where negative circumstances cannot be identified without the use of special knowledge), level of his intellectual development, education and so on.
Often, the investigator is faced with the problem of detecting traces of staging during the inspection of the crime scene. Scientists and practitioners have always agreed that the review is the most informative for investigation, because it always has important tactical tasks, in particular: study and fixation of the crime scene in order to identify the nature and mechanism of the crime; identifying and removing traces of crime that may later be used as a sources of evidential information; establishing the features that characterize the persons involved in the crime; fixation of features which are inherent to the victim and another object of encroachment; establishing circumstances that always take into account the objective side of the crime (the time, the manner of its commission, the actions of the criminal at the crime scene, the consequences of the criminal acts); establishment of signs which indicate the motive and purpose of the crime; establishing the circumstances that facilitate the commission of the crime, etc. $[10$, c. 13$]$.

Specificity of the review is searching, detection, capture and analysis by investigator the features, properties, status and relative location of objects, which are relevant to criminal investigation [8, c. 118], in particular, a detailed study of the crime scene.

From our point of view, the concept of "crime scene" in criminalistics literature has two approaches to understanding: narrow and broad. In the narrow, it is the setting of the crime scene as a set of objects of the material world; in the broad - a larger category that characterizes a set of factors, which explains the set of factors that influence criminal activity in the process of its preparation, committing and further concealing and reflects the behaviour of direct and indirect participants in the crime. However very often personal knowledge and experience of the investigator is not enough to solve all these tasks and a thorough study of the crime scene in its broadest sense.

It should be notice, that the study of the immediate crime scene requires a combination of prior and expert research. A.F. Volobuiev considers prior research as a kind of cognitive activity which has nonprocedural nature and carried out by the investigator independently, and with the involvement of a specialist in the scrutinizing and evaluation of the material traces of the crime discovered in the course of investigative actions. In this process, the investigator or specialist, using his or her specific knowledge and applying scientific and technical means and methods: a) determines the relativity of the detected traces to the investigated event; $b$ ) establishes the mechanism of their formation and the signs of trace-forming objects; c) receives indicative data about the anatomical, professional and other characteristics of the perpetrator, about the mechanism of the crime and other circumstances that are relevant in the case [3, c. 13-14]. Preliminary research allows the investigator: a) assess the situation in which the investigation will take place; b) identify the main directions of the criminal's searching; c) create a plan of priority investigative and detective actions that should be carried out for this purpose. Expert research also provides the investigator with information regarding the reasonable assumptions about the circumstances of the event and the offender, as they are based on specific research results.

Therefore, in addition, the conduction of expertise is an important form of using special knowledge to obtain information about the offender. According to their results, a person may be identified by fingerprints found at the crime scene or on the instruments or 
other objects of a criminal assault discovered during the course of the investigation during the realization of investigative actions (inspection, search, examination, investigative experiment, etc.). Also, an expert can establish various features of the offender: age, gender, height, constitution, certain functional characteristics, professional skills, psychological characteristics of the offender. This information about the identity of the unknown offender can be obtained from the results of various judicial examinations, including fingerprinting, tracological examination of footprints or bare feet, forensic, biological, ballistic, handwriting and other examinations.

Moreover, the special knowledge of the investigator and expert can be used to prepare for the conduct of investigative actions involving the suspect or witness in cases where the investigator needs to be trained and consulted on the use of certain knowledge. Such knowledge can be used in various investigative activities and will allow the investigator to obtain new or confirm available information about the offender's identity.

Also currently there is a group of crimes, which investigation is basically impossible without special knowledge. These are crimes that are referred to as "cybercrime" (or "cybercriminality"). This concept was first introduced in foreign literature in the $1960 \mathrm{~s}$ [9, p. 173].

Modern developed world faces the problem when cybercrime poses a significant threat and causes significant damage $t$ to people around the world.

Modern developed world faces the problem when cybercrime poses a significant threat and causes significant damage to citizens of Ukraine as well as to people around the world. The legal definition of cybercrime is absent in national legislation, which gives rise to constant discussions among scientists about the nature and content of this manifestation of crime and the different approaches to the classification of wrongdoing that may be attributed to a particular group of offenses by one or another attribute.

The specificity of identifying the personality of an unknown criminal in a cybercrime investigation is related to the particularities of the mechanism of this kind of crime, to which scientists include: increased concealment of the fact and method of committing the crime, which is ensured by the specificity of the network information space; the cross-border nature of network crimes, where the offender, the target of the criminal offense, the victim may reside in the territories of different states; remote nature of criminal acts in the absence of physical contact between the offender and the victim; special skills of the offender, intellectual character of criminal activity; non-standardity, complexity, variety and frequent updating of crimes and special technical means which are used; the possibility of committing a crime in an automatic mode in several places at the same time; the use of computers as tools of crime; the multi-episode nature of the crime and the large number of victims; the ignorance of the victims that they were victims of crime [9, p. 175-176].

Therefore, identifying information about the identity of a cybercrime perpetrator is directly related to the study of the perpetration of such a crime - cyberspace [For more details see: 5]. O.A. Samoilenko notes that cyberspace simultaneously acts as a place of formation of traces of crime and a source of tools and means of implementing the mechanism of criminal assault $[12$, p. 181]. Moreover, along with the traditional traces of a criminal event, such as fingerprints, footprints, blood, saliva, memories of victims and witnesses, for cybercrime is characterized by the formation of a criminal's trace in cyberspace - certain information networks. A.H. Volevodz notes that computer information can be both source of information about the offender and his / her illegal activities, as well as a direct trace of the crime $[2$, p. 4] - its virtual reflection, formed in cyberspace or stored on special media of digital information as a result of the offender's actions in order to realize a certain criminal intent. Finding, detecting, fixing, deleting, and further investigating such "virtual footprints" requires the use of special knowledge. The ability to investigate information contained in "virtual footprints" that can be used to identify an unknown criminal is related to the existence of special $\log$ files (LOGs) of streaming data. Such registers may contain user information and messages transmitted. This can be information about your name, address, date of birth, phone number, bank card information, email address, browsing history, etc. However, finding this information requires some effort on the part of the person with special knowledge.

Conclusions. To sum up, the usage of special knowledge to identify the offender is implemented not only within the framework of individual examinations, as a solely or a single action, but as some ongoing activity, which is an integral part of the criminal investigation. The usage of certain special knowledge is realized directly on the background of the investigative activity itself and serves as one of its tools for dealing with evidence and oriented information about the offender. The role of the utilization of special knowledge in the investigation for the purpose of establishing all the circumstances of the criminal event and identifying and exposing the offender is extremely high and varies depending on the category of investigated crime.

\section{References:}

1. Аленин Ю.П., Тищенко В.В. Особенности расследования тяжких преступлений против личности : учебное пособие. Одесса : АО Бахва, 1996. 112 с.

2. Волеводз А.Г. Следы преступлений, совершенных в компьютерных сетях. Российский следователь. 2002. № 1. С. 4-12.

3. Волобуєва О.О. Взаємодія слідчого з фахівцями під час збору інформації про особу, що скоїла злочин : автореф. дис. ... канд. юрид. наук : 12.00 .09 . Київ, 2006. 20 c.

4. Гресь Ю.О. Місце події як джерело інформації про особу злочинця. Правове життя сучасної України : у 2 т. : матеріали Міжнар.наук.-практ. конф. (м. Одеса, 17 трав. 2019 р.). Одеса : Видавничий дім «Гельветика», 2019. Т. 2. С. 407-409.

5. Динту В.А. Місце кіберпростору в системі обстановки злочину. Науковий вісник Херсонського державного університету. 2016. Вип. 2. Т. 3. С. $72-75$.

6. Калюга К.В. Властивості людини як елемент криміналістичної характеристики, що відображається у матеріальному середовищі під час вчинення злочину. Криміналістичний вісник. 2010. № 1 (13). C. 186-191.

7. Криміналістика : підручник / за ред. В.В. Тіщенка. Одеса : Видавничий дім «Гельветика», 2017. 556 с.

8. Криміналістична тактика : навчальний посібник /за ред. М.А. Погорецького та Д.Б. Сергєєвої. Київ : Алерта, 2016. 244 с.

9. Міщук Н. Кіберзлочинність як загроза інформаційному суспільству. Вісник Львівського університету. Серія «Економічна». 2014. Вип. 51. С. 173-179.

10. Осмотр места происшествия : практическое пособие /под ред. А.И. Дворкина. Москва : Юристъ, 2001. 336 с.

11. Рожик Є.М. Місце негативних обставин у системі наслідків злочину. Прикарпатський юридичний вісник. 2018. Вип. 4 (25). T. 3. C. $129-132$. 
12. Самойленко О.А. Природа кіберпростору як об'єкта криміналістичного дослідження. Криміналістика і судова експертиза. 2018. Вип. 63 (1). С. 174-184.

13. Тищенко В.В. Технология доказывания виновности подозреваемого. Юридичний вісник. 2015. № 4. С. 154-162.

Гресь Ю. О., Динту В. А. Особливості використання спеціальних знань 3 метою встановлення особи злочинця

Анотація. Під час здійснення розслідування перед слідчим постає важливе та досить складне завдання, що стосується встановлення винної особи, ії виявлення й затримання з метою притягнення до кримінальної відповідальності. Успішність і результативність такої діяльності прямо залежить від уміння слідчого працювати з інформацією та користуватися всім різноманіттям наявного в нього інструментарію, серед якого важливе місце посідають спеціальні знання. Під час розслідування слідчий може користуватися власними спеціальними знаннями, а також звертатися до спеціалістів та експертів. Такі спеціальні знання можуть використовуватися для пошуку й попереднього оцінювання певної інформації слідчим і спеціалістом 3 метою консультування до й під час проведення слідчих дій у вигляді проведення експертних досліджень.
Спеціальні знання слідчого, спеціаліста та експерта дають змогу виявляти різноманітну інформацію, що може вказати на характерні особливості зовнішності, характеру, поведінки особи невідомого злочинця. Оцінювання обстановки місця події з позиції використання спеціальних знань дає можливість змоделювати особу невідомого злочинця, що є надзвичайно важливим особливо на початковому етапі розслідування.

Застосування спеціальних знань дає слідчому змогу виявити існування певних негативних обставин на місці події. Своєчасне встановлення обставин, що не відображають дійсну картину злочинної події, допомагає уникнути прийняття хибних рішень і помилок. Також виявлення негативних обставин може навести слідчого на правильний вибір напряму здійснення розслідування.

Важливим напрямом використання спеціальних знань під час пошуку й установлення злочинця $є$ застосування знань у сфері інформаційних технологій. Сьогодні розслідування багатьох злочинів вимагає дослідження злочинів, що скоюються в кіберпросторі.

Ключові слова: злочин, слід, матеріальні сліди, ідеальні сліди, особа злочинця, спеціальні знання, кіберзлочинність, кіберпростір, віртуальні сліди. 